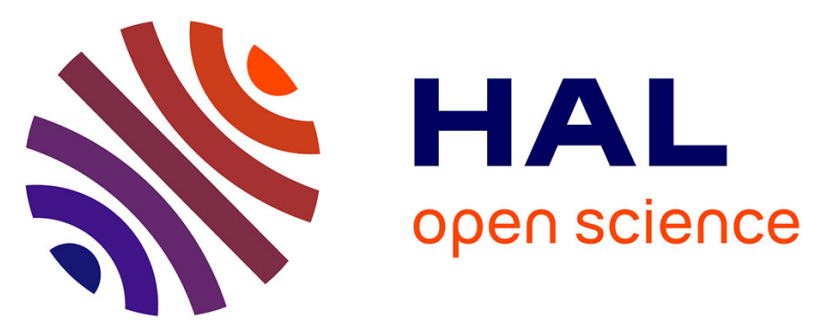

\title{
Physico-chemical characterization and in vitro biological evaluation of pure SiHA for bone tissue engineering application
}

\author{
David Marchat, Guénaëlle Bouet, Aline Ludeckgen, Maria Zymelka, Luc \\ Malaval, Stephanie Szenknect, Nicolas Dacheux, Didier Bernache-Assollant, \\ Jérome Chevalier
}

\section{To cite this version:}

David Marchat, Guénaëlle Bouet, Aline Ludeckgen, Maria Zymelka, Luc Malaval, et al.. Physico-chemical characterization and in vitro biological evaluation of pure SiHA for bone tissue engineering application. Key Engineering Materials, 2013, 529-530, pp.351-356. 10.4028/www.scientific.net/KEM.529-530.351 . hal-00734831

\section{HAL Id: hal-00734831 \\ https://hal.science/hal-00734831}

Submitted on 24 Sep 2012

HAL is a multi-disciplinary open access archive for the deposit and dissemination of scientific research documents, whether they are published or not. The documents may come from teaching and research institutions in France or abroad, or from public or private research centers.
L'archive ouverte pluridisciplinaire HAL, est destinée au dépôt et à la diffusion de documents scientifiques de niveau recherche, publiés ou non, émanant des établissements d'enseignement et de recherche français ou étrangers, des laboratoires publics ou privés. 


\title{
Physico-chemical characterization and in vitro biological evaluation of pure SiHA for bone tissue engineering application
}

\author{
Marchat David $^{1,}$, , Bouët Guénaëlle ${ }^{2}$, Lueckgen Aline ${ }^{1}$, Zymelka Maria ${ }^{1}$, \\ Malaval Luc ${ }^{2}$, Szenknect Stéphanie ${ }^{3}$, Dacheux Nicolas ${ }^{3}$, Bernache-Assollant \\ Didier $^{1}$, Chevalier Jérôme ${ }^{4}$ \\ ${ }^{1}$ Ecole Nationale Supérieure des Mines de Saint-Etienne, CIS-EMSE, CNRS: FRE3312, F-42023 \\ 158 Cours Fauriel, Saint-Etienne, France. \\ ${ }^{2}$ Université Jean Monnet/PRES Université de Lyon, Faculté de Médecine, LBTO/Inserm U1059, \\ F-42023, 15 rue Paré, Saint-Etienne, France \\ ${ }^{3}$ Université de Montpellier 2, Lab. des Interfaces de Matériaux en Evolution (LIME), Institut de \\ Chimie Séparative de Marcoule - UMR 5257, BP 17171, 30207 Bagnols sur Cèze cedex, France \\ ${ }^{4}$ Université de Lyon, INSA-Lyon, MATEIS Laboratory UMR CNRS 5510, Villeurbanne F-69621, \\ France \\ amarchat@emse.fr
}

Keywords: silicon-substituted hydroxyapatite, bioceramics, dissolution, in vitro biocompatibility

\begin{abstract}
Studies about silicon-substituted hydroxyapatites exhibit several shortcomings that leave unanswered questions regarding the properties and subsequent biological outcomes generated by this biomaterial. Firstly, samples characterization is often incomplete, meaning that phase purity on the pellet surface is not assured. In fact, ceramic materials used in literature that are claimed to be pure are actually polluted through second phase as superficial polymerized silicate.

In this study, we have successfully synthesized a phase-pure silicon hydroxyapatite powder $\mathrm{Ca}_{10}\left(\mathrm{PO}_{4}\right)_{5.5}\left(\mathrm{SiO}_{4}\right)_{0.5}(\mathrm{OH})_{1.5}\left(\mathrm{Si}_{0.5} \mathrm{HA}\right)$ compressed this powder into pellets, sintered them, and evaluated the biological response of osteoblast cells (C3H10 line) seeded on the pellet surface. Besides, the solubility in aqueous media of $\mathrm{HA}$ and $\mathrm{Si}_{0.5} \mathrm{HA}$ pellets were determined through "static" experiments. These tests attempt to provide a comprehensive picture of the cellular response to the SiHA material, in order to determine the mechanism by which Si evokes the improved in vitro biological outcomes described in the literature. Results revealed first an equivalent solubility of $\mathrm{Si}_{0.5} \mathrm{HA}$ and HA pellets, and second that cells do not react favourably to the pure SiHA surface.
\end{abstract}

\section{Introduction}

Large bone defects resulting from trauma, cancer or malformations remain significant clinical problems. The use of autografts, allografts or currently available synthetic biomaterials is not really suitable for such cases. Among synthetic biomaterials, hydroxyapatite $\left(\mathrm{HA}, \mathrm{Ca}_{10}\left(\mathrm{PO}_{4}\right)_{6}(\mathrm{OH})\right)$ ceramics have been used as synthetic bone graft substitutes for more than 30 years due to their bioactivity, osteoconductivity and biocompatibility with the human tissue. However, HA shows limited ability to stimulate the development of new bone tissue and has a very low rate of biodegradation. To further improve its biological properties and extend its clinical applications, ionic substitution into the HA crystal lattice has been tested. One of the most promising candidate appeared to be the silicate ion, which replaces phosphate in order to yield a silicated hydroxyapatite (SiHA, $\left.\mathrm{Ca}_{10}\left(\mathrm{PO}_{4}\right)_{6-\mathrm{y}}\left(\mathrm{SiO}_{4}\right)_{\mathrm{y}}(\mathrm{OH})_{2-\mathrm{y}}\right)$.

Previous studies have shown beneficial biological properties of SiHA compared to HA, as rapid bone apposition and angiogenesis, faster bone maturity, and a higher solubility [1-5]. Unfortunately, a lot of questions remain regarding these results. Recent critical reviews highlighted the lack of experimental evidence which could explain the real effects of Si substitution on the biological activity of HA in biological environment [6-8]. 


\section{Materials and Methods}

Synthesis and pellets preparation. $\mathrm{HA}$ and $\mathrm{Si}_{0.5} \mathrm{HA}$ powders were prepared according to the protocol described in detail elsewhere [9]. Reagents ratio used to prepare the $\mathrm{Si}_{0.5} \mathrm{HA}$ powders were calculated according to the formula $\mathrm{Ca}_{10}\left(\mathrm{PO}_{4}\right)_{5.5}\left(\mathrm{SiO}_{4}\right)_{0.5}(\mathrm{OH})_{1.5}$ and a constant molar ratio $\mathrm{Ca} /(\mathrm{P}+\mathrm{Si})$ equals to $10 / 6$. Precipitation was performed at $50^{\circ} \mathrm{C}, \mathrm{pH}$ value $10.80 \pm 0.05$ for $24 \mathrm{~h}$. After filtration the as-synthesized powder was first dried at $80^{\circ} \mathrm{C}$ for $24 \mathrm{~h}$, then grinded manually with agate mortar and pestle. Before shaping and sintering $\mathrm{HA}$ and $\mathrm{Si}_{0.5} \mathrm{HA}$ were precalcined at $700^{\circ} \mathrm{C}$ for $1 \mathrm{~h}$ and $900^{\circ} \mathrm{C}$ for $2 \mathrm{~h}$, respectively, in order to adjust their $\mathrm{S}_{\mathrm{BET}}$ surface area at about $25 \mathrm{~m}^{2} \cdot \mathrm{g}^{-1}$. Then, pellets were obtained by first a uniaxial pressing at $40 \mathrm{MPa}$ of $450 \mathrm{mg}$ of powder in a $12.6 \mathrm{~mm}$ diameter stainless steel die, followed by a cold isostatic pressing under $300 \mathrm{MPa}$. Pellets were sintered in a Super Kanthal furnace (Nabertherm LH30, Germany) in an air atmosphere at $1,150^{\circ} \mathrm{C}$ for $2 \mathrm{~h}$. The heating and cooling rates were fixed at $4^{\circ} \mathrm{C} / \mathrm{min}$. This sintering temperature was chosen to avoid the SiHA decomposition as well as to get an equivalent topography of the pellets surface. Finally, sintered pellets were mirror polished up to $1 \mu \mathrm{m}$ diamond paste.

Pellets physico-chemical characterization. Crystalline phases were identified on polished pellets by means of a $\theta / 2 \theta$ X-ray diffractometer (XRD) Siemens D5000 using CuK $\alpha$ radiation at the operating conditions $40 \mathrm{kV}$ and $20 \mathrm{~mA}$. XRD patterns were collected over $2 \theta$ range of $24-41^{\circ}$ at the step size of $0.03^{\circ}$ and counting time of $13.5 \mathrm{~s}$ per step in order to determine the phase composition. Fourier Transformed Infrared (FT-IR) measurements were carried out with the use of a Spectrometer Bruker HYPERION 2000 equipped for ATR mapping. The ATR objective is composed of an external crystal allowing the analysis of polished surface. The spectra were recorded over the range 450-4000 $\mathrm{cm}^{-1}$ with a resolution of $2 \mathrm{~cm}^{-1}$. They are an average of 128 successive scans. Finally, spectra were normalized according to the classical procedure $[10,11]$. The dissolution tests were performed using "static" conditions described in details previously $[8,12]$. Tests were performed on $\mathrm{HA}$ and $\mathrm{Si}_{0.5} \mathrm{HA}$ pellets sintered at $1,200^{\circ} \mathrm{C}$ and $1,000^{\circ} \mathrm{C}$ for $2 \mathrm{~h}$, respectively. Their 5 points BET surface areas $\left(\mathrm{S}_{\mathrm{BET}}\right)$, determined using a Micrometric ASAP 2020 apparatus under nitrogen atmosphere, are equal to 0.4 and $1.5 \mathrm{~m}^{2} \cdot \mathrm{g}^{-1}$, respectively. The normalized mass loss $\mathrm{N}_{\mathrm{L}}$ (i;t) (in g.m-2), for $i$ element and a dissolution time $\mathrm{t}$, was calculated according to the concentrations in solution determined by Inductively Coupled Plasma Atomic Emission Spectrometry (ICP/AES) and the equation presented previously [12].

In vitro biological evaluation. The $\mathrm{C}_{3} \mathrm{H}_{10}$ cell line was used for all biological evaluations. Cells were cultured in Dulbecco's Modified Eagle Medium supplemented with $2 \mathrm{mM}$ glutamine, 50U/mL penicillin, $50 \mathrm{mg} / \mathrm{mL}$ streptomycin, $10 \%$ foetal calf serum (FCS), and the osteogenic differentiation factors ascorbic acid $(50 \mu \mathrm{g} / \mathrm{mL})$ and $\beta$-glycerophosphate $(10 \mathrm{mM})$. Ceramic pellets were sterilized at $180^{\circ} \mathrm{C}$ for 30 minutes prior to cell seeding. Pellets were placed in individual wells of a 24 -well plate and cultured in $1 \mathrm{~mL}$ of medium. The plastic surface of culture wells without pellets was used as a positive control. Cells were trypsinized after passage 18 and seeded on the surface of each pellet and in control wells at a density of 5,000 cells.cm ${ }^{-2}$. Cultures were then incubated at $37^{\circ} \mathrm{C}$ with $5 \% \mathrm{CO}_{2}$ and cell media was changed every 2-3 days. All reagents were purchased from Sigma, Saint-Quentin Fallavier, France. The growth of cell populations was determined using the MTT Viability Test [3-(4,5-Dimethylthiazol-2-yl)-2,5-diphenyltetrazolium bromide - Sigma], which was conducted after $1,3,6$, and 8 days of culture. This assay is based on the enzymatic reduction of the MTT reagent linked to the production of purple color which is quantified by absorbance measurement using a spectrophotometer. For each measurement, cells were rinsed twice with DMEM without serum and $0.1 \%$ BSA before incubation with MTT dye at a concentration of 1:10 for 4 hours. Cells were then incubated for 45 minutes, the last 5 of which, under mild agitation. Using a Thermo Multiskan Spectrum spectrophotometer, the absorbance at 570nm was measured. The cell proliferation was monitored through the incorporation of the pyrimidine analogue 5-bromo-2'-deoxyuridine (BrdU) into DNA, which can be detected by immunoassay (Roche Applied Science). On the third and sixth 
days of culture, the cells were incubated with the BrdU labeling solution at a concentration of 1:10 in culture medium for 2 hours at $37^{\circ} \mathrm{C}$. After denaturation, labeling with an anti-BrdU antibody conjugated with peroxidase, and washing, the absorbance was measured at $370 \mathrm{~nm}$ with a reference reading at $492 \mathrm{~nm}$ (Thermo Multiskan Spectrum spectrophotometer). All proliferation absorbance readings were normalized to the absorbance for that time point obtained by the cell growth assay to effectively determine the ratio of proliferating cells in each condition. Finally, in order to prepare samples for SEM imaging, pellets were fixed with $2.5 \%$ glutaraldehyde for 20 minutes, rinsed with Phosphate Buffered Saline (PBS), and then dehydrated in successive acetone baths ranging from 30\% to $99 \%$, lasting 10 minutes each. Just prior to imaging, pellets were coated with a thin gold layer by the low vacuum sputter coating method to create an electrically-conductive surface.

\section{Results and Discussions}

X-ray diffraction patterns of both $\mathrm{HA}$ and $\mathrm{Si}_{0.5} \mathrm{HA}$ pellets (Figure 1) exhibit only the characteristic diffraction lines of the hydroxyapatite HA (PDF 09-432). IR spectra of $\mathrm{HA}$ and $\mathrm{Si}_{0.5} \mathrm{HA}$ pellets surface (Figure 2) show the vibration bands of phosphate groups at $475\left(v_{2}\right), 564\left(v_{4}\right), 600\left(v_{4}\right), 962$ $\left(v_{1}\right), 1024\left(v_{3}\right)$ and $1087\left(v_{3}\right) \mathrm{cm}^{-1}$, and the ones of hydroxide groups at $628\left(v_{L}\right)$ and $\left(v_{S}\right) 3570 \mathrm{~cm}^{-1}$ that are characteristic of calcium hydroxyapatite. However, the intensity of the stretching and librational modes of the hydroxide groups are lower for SiHA than for HA, as already described [9]. Besides, SiHA spectrum displays bands and shoulders (sh) related to the incorporation of Si into the hydroxyapatite structure: 492 (sh), 504, 525, 750, 835 (sh), 889, 981 (sh) and 1000 (sh) $\mathrm{cm}^{-1}$ [9]. On the other hand, no IR band due to silica (e.g. $683,798,870 \mathrm{~cm}^{-1}$ ) or tricalcium phosphate (e.g. 495 , $567,945,1013,1025$ or $1055 \mathrm{~cm}^{-1}$ [13]) is detected. The surface of the HA and $\mathrm{Si}_{0.5} \mathrm{HA}$ pellets are monophasic and free of crystalline or amorphous second phases. The sintering heat-treatment at $1150^{\circ} \mathrm{C}$ for $2 \mathrm{~h}$ does not decompose the SiHA phase and allows getting equivalent surface topography (Figure 3).

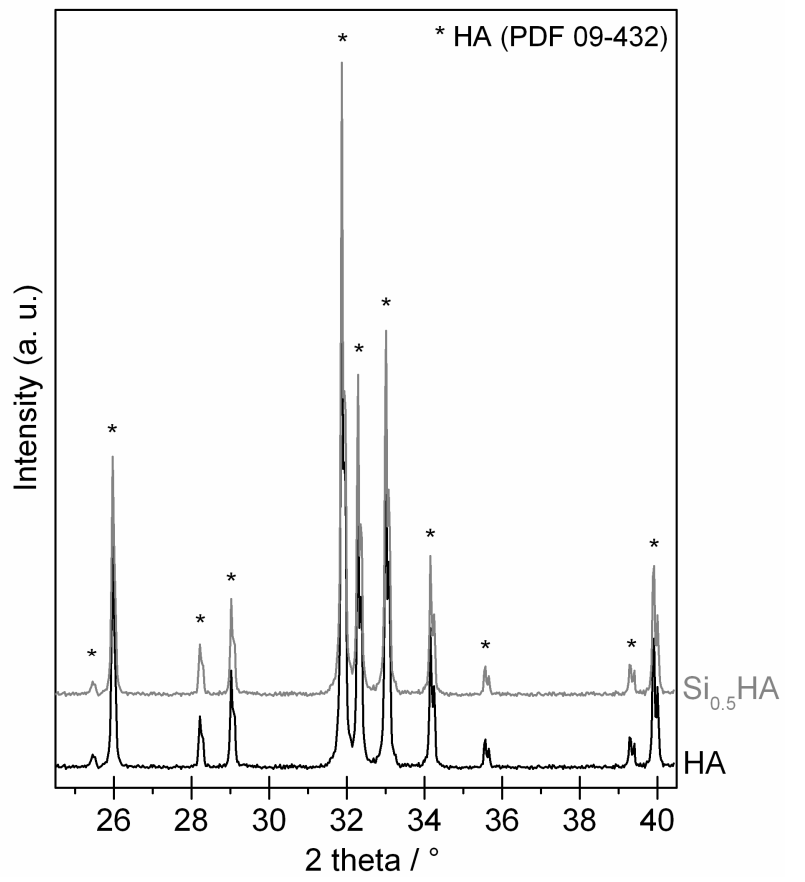

Figure 1. XRD patterns of $\mathrm{HA}$ and $\mathrm{Si}_{0.5} \mathrm{HA}$ sintered and polished pellets.

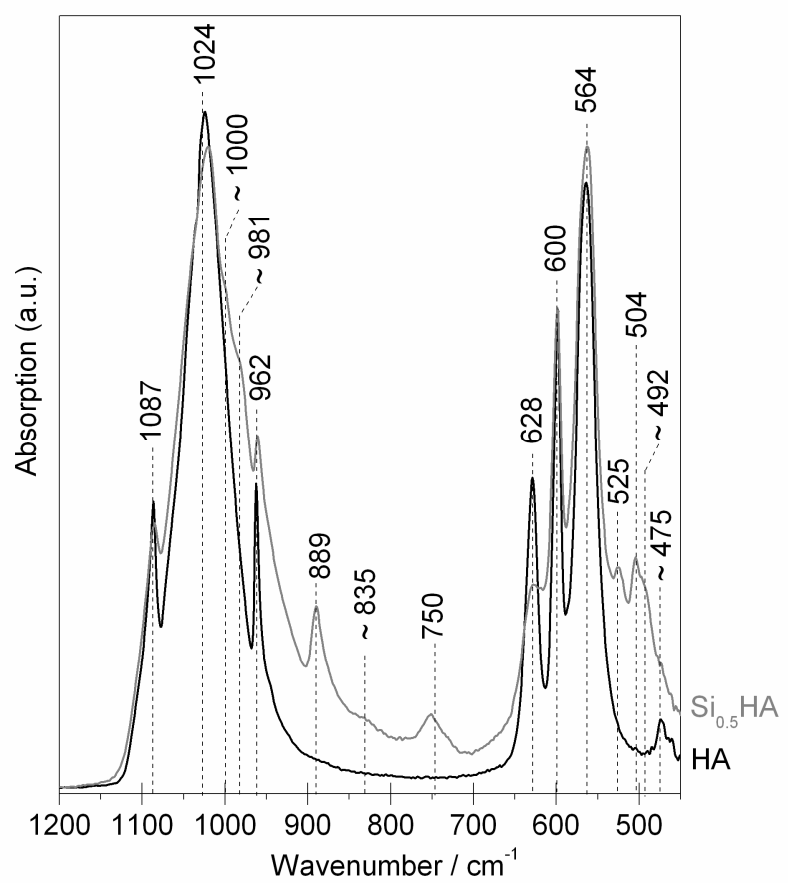

Figure 2. FTIR spectra of $\mathrm{HA}$ and $\mathrm{Si}_{0.5} \mathrm{HA}$ sintered and polished pellets. 

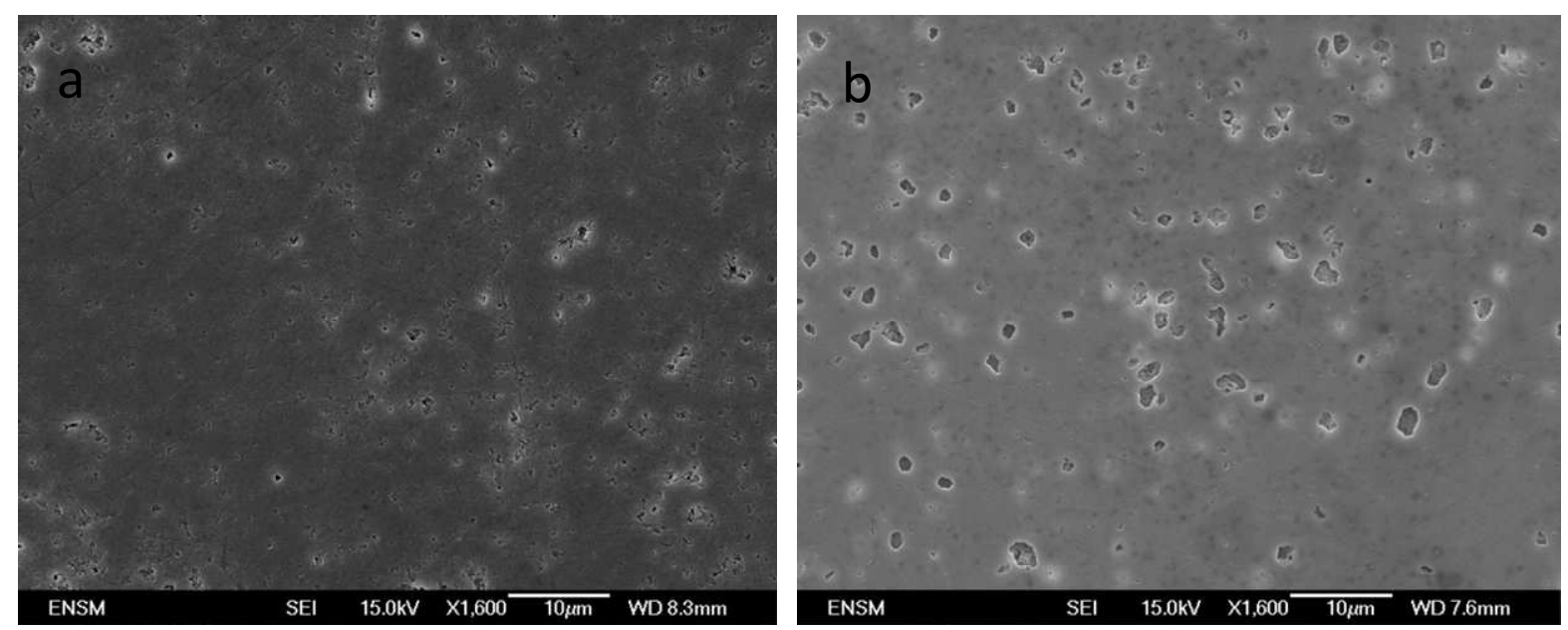

Figure 3. SEM micrographs of the surface of (a) $\mathrm{HA}$ and (b) $\mathrm{Si}_{0.5} \mathrm{HA}$ polished pellets before biological evaluation.

Ions concentrations measured at the equilibrium $(\mathrm{t}=144 \mathrm{~h})$ after dissolution in $\mathrm{HNO}_{3}$ solutions $\left(5.10^{-3}\right.$ and $\left.0.1 \mathrm{M}\right)$ of powders and pellets are not significantly different (see Table 1). It confirms that these pulverulent or sintered samples have a similar solubility behavior. Yet, it was determined that $\mathrm{HA}$ and $\mathrm{Si}_{0.5} \mathrm{HA}$ powders exhibit an equivalent solubility product range between $138 \geq \mathrm{pK}_{\mathrm{s}} \geq 123$ [8].

Table 1. Ca, $\mathrm{P}$ and Si concentrations at the equilibrium (144h) and related normalized mass loss $\left(\mathrm{N}_{\mathrm{L}}\right)$ of $\mathrm{HA}$ and $\mathrm{Si}_{0.5} \mathrm{HA}$ powders and pellets in $\mathrm{HNO}_{3}$ solution at $0.1 \mathrm{M}$

\begin{tabular}{|l|c|c|c|c|c|c|c|c|}
\hline & $\mathrm{m}$ & $\mathrm{V}$ & {$[\mathrm{Ca}]$} & {$[\mathrm{P}]$} & {$[\mathrm{Si}]$} & $\mathrm{N}_{\mathrm{L}}(\mathrm{Ca})$ & $\mathrm{N}_{\mathrm{L}}(\mathrm{P})$ & $\mathrm{N}_{\mathrm{L}}(\mathrm{Si})$ \\
\hline & $/ \mathrm{g}$ & $/ \mathrm{L}$ & $/ \mathrm{mol} . \mathrm{L}^{-1}$ & $/ \mathrm{mol} . \mathrm{L}^{-1}$ & $/ \mathrm{mol}^{-1}$ & $/ \mathrm{mg} \cdot \mathrm{m}^{-2}$ & $/ \mathrm{mg}^{-2}$ & $/ \mathrm{mg} \cdot \mathrm{m}^{-2}$ \\
\hline Powder HA & 0.20 & 0.020 & $7.2510^{-2}$ & $4.3510^{-2}$ & - & 979.0 & 981.4 & - \\
\hline Pellet HA & 0.25 & 0.010 & $7.5010^{-2}$ & $4.4810^{-2}$ & - & 756.2 & 753.0 & - \\
\hline Powder SiHA & 0.21 & 0.020 & $6.9610^{-2}$ & $4.1610^{-2}$ & $3.2610^{-3}$ & 273.1 & 269.5 & 226.7 \\
\hline Pellet SiHA & 0.23 & 0.010 & $7.3610^{-2}$ & $3.9210^{-2}$ & $3.9010^{-3}$ & 199.6 & 193.3 & 211.6 \\
\hline
\end{tabular}

Cell growth and cell proliferation are presented on Figures 4 and 5 respectively. Figure 4 indicate that pure $\mathrm{Si}_{0.5} \mathrm{HA}$ pellet surface does not foster prolonged cell growth conversely to the HA one. A two-way ANOVA with repeated measures confirms that both time and the composition of the substrate affect cell growth. Cell proliferation after three days is significantly greater on HA than on pure SiHA. Though the ratio of normalized proliferating cells (Figure 5b) is equivalent for both conditions at day 6 , too few cells are present on the pure $\mathrm{Si}_{0.5} \mathrm{HA}$ pellets for the cell growth to catch up with HA (Figure 5a). The SiHA ability to promote cell proliferation in early cultures falls short of the HA. SEM images show that HA surface is entirely covered by ECM proteins while the substrate porosity is still visible on pure $\mathrm{Si}_{0.5} \mathrm{HA}$ (Figure 6). It indicates that cells seeded on this surface did not deposit matrix. Moreover, cells seeded on HA surface adhered, and broadly spread out to cover the surface. In contrast, cells on the pure $\mathrm{Si}_{0.5} \mathrm{HA}$ pellets remain balled up and formed only few direct contact sites with the substrate.

Osteoblast cells clearly do not react favorably to the pure $\mathrm{Si}_{0.5} \mathrm{HA}$ phase. This phenomenon does not arise from the non-therapeutic release of silicon or calcium within the media since $\mathrm{HA}$ and $\mathrm{Si}_{0.5} \mathrm{HA}$ show an equivalent and very low solubility product. Likewise, topographical effects are not relevant. The surface chemistry and more especially the $\mathrm{Si}-\mathrm{OH}$ groups at the $\mathrm{Si}_{0.5} \mathrm{HA}$ surface could modify cell attachment, movement, proliferation or differentiation through conformational changes in extracellular matrix proteins. 


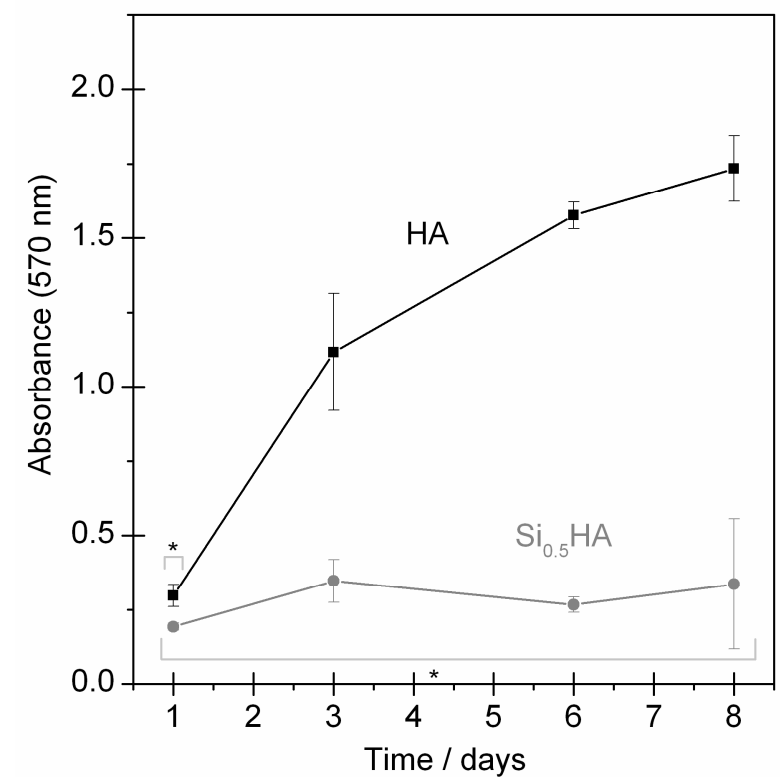

Figure 4. Cell growth on $\mathrm{HA}$ and $\mathrm{Si}_{0.5} \mathrm{HA}$ polished pellets after $1,3,6$, and 8 days of culture. $* \mathrm{P}<0.05$

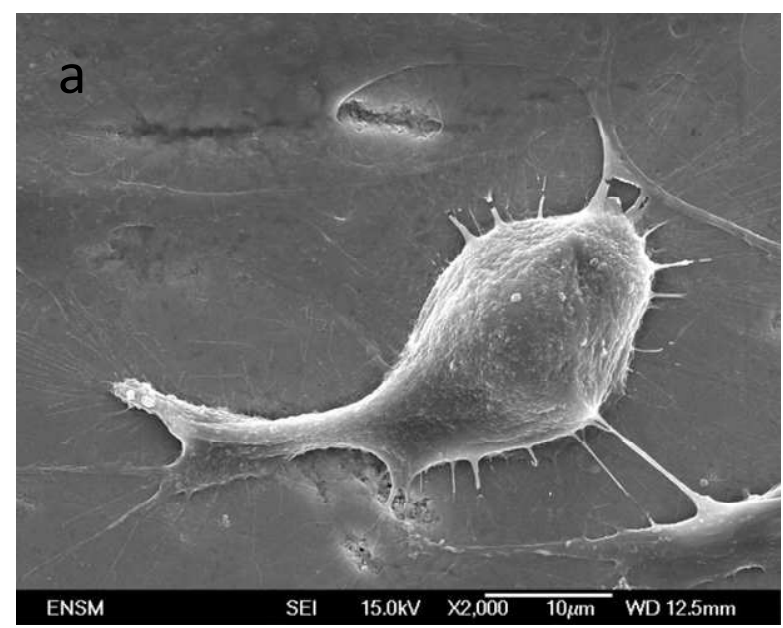

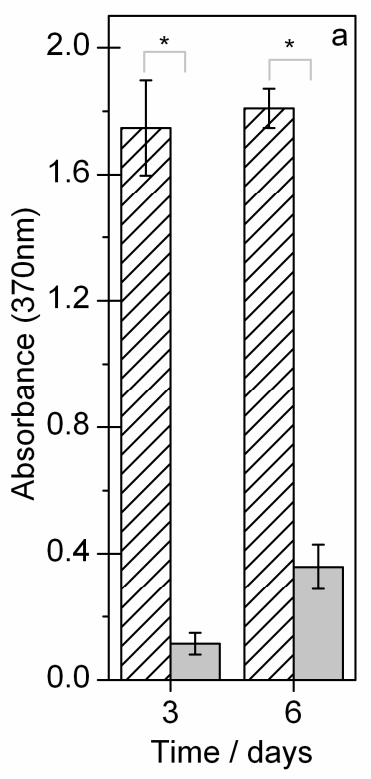

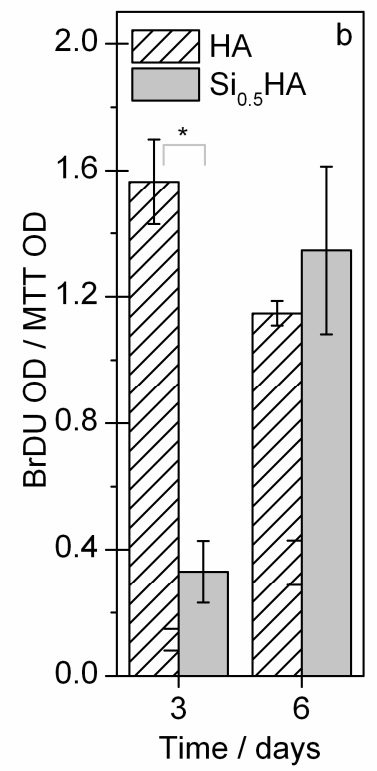

Figure 5. Cell proliferation on HA and Si0.5HA pellets (a) BrDU absorbance, (b) BrDU absorbance adjusted to MTT. $* \mathrm{P}<0.05$

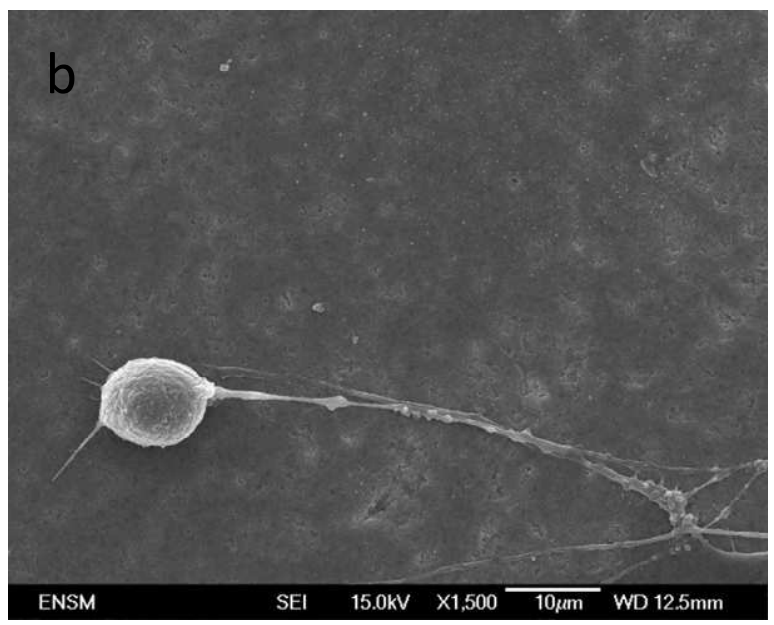

Figure 6. SEM micrographs of (a) $\mathrm{HA}$ and (b) $\mathrm{Si}_{0.5} \mathrm{HA}$ pellet surfaces after 3 days of culture with $\mathrm{C}_{3} \mathrm{H}_{10}$ cells.

\section{Conclusion}

This study reveals that cells seeded on pure $\mathrm{Si}_{0.5} \mathrm{HA}\left(\mathrm{Ca}_{10}\left(\mathrm{PO}_{4}\right)_{5.5}\left(\mathrm{SiO}_{4}\right)_{0.5}(\mathrm{OH})_{1.5}\right)$ pellets do not grow, and proliferate less than those on HA substrate after 3 days of culture. It seems that many cells simultaneously undergo cell death. The positive biological outcomes of silicon-substituted hydroxyapatites claimed by literature are not confirmed for pure silicon-substituted hydroxyapatite phase. Surface chemistry of the $\mathrm{Si}_{0.5} \mathrm{HA}$ ceramic seems disturbing the deposition of ECM, and affecting the ability of the osteoblast cells to attach, to move and more generally to survive. 


\section{References}

[1] Best SM, Zou S, Brooks RA, Huang J, Rushton N, Bonfield W. The osteogenic behaviour of silicon substituted hydroxyapatite. Key Engineering Materials 2008;361-363:985-8.

[2] Hing KA, Wilson LF, Buckland T. Comparative performance of three ceramic bone graft substitutes. The Spine Journal 2007;7:475-90.

[3] Pietak AM, Reid JW, Stott MJ, Sayer M. Silicon substitution in the calcium phosphate bioceramics. Biomaterials 2007;28:4023-32.

[4] Porter AE, Buckland T, Hing KA, Best SM, Bonfield W. The structure of the bond between bone and porous Si-HA bioceramic implants. Journal of Biomedical Materials Research 2006;78A:25-33. [5] Porter AE, Patel N, Skepper JN, Best SM, Bonfield W. Comparison of in vivo dissolution processes in hydroxyapatite and silicon-substituted hydroxyapatite bioceramics. Biomaterials 2003;24:4609-20.

[6] Boanini E, Gazzano M, Bigi A. Ionic substitutions in calcium phosphates synthesized at low temperature. Acta Biomaterialia 2010;6:1882-94.

[7] Bohner M. Silicon-substituted calcium phosphates - A critical view. Biomaterials 2009;30:6403-6.

[8] Zymelka M, Marchat D, Szenknect S, Dacheux N, Bernache-Assollant D, Chevalier J. Silicon-substituted hydroxyapatite particles precipitation and dissolution. Acta Biomaterialia 2012;(Submitted).

[9] Marchat D, Zymelka M, Gremillard L, Coelho C, Joly-Pottuz L, Babonneau F, et al. Accurate characterization of silicon-substituted hydroxyapatites powders synthesized by a new precipitation route. Acta Biomaterialia 2012;(Submitted).

[10] Marchat D, Bernache-Assollant D, Champion E. Cadmium fixation by synthetic hydroxyapatite particles in aqueous solution - Kinetic study. Journal of Hazardous Materials 2011;to be submitted.

[11] Rey C, Collins B, Goehl T, Dickson IR, Glimcher MJ. The carbonate environment in bone mineral: a resolution enhanced Fourier transform infrared spectroscopy study. Calcified Tissue International 1989;45:157-64.

[12] Dacheux N, Du Fou de Kernadiel E, Clavier N, Podor R, Aupias J, Szenknect S. Kinetics of dissolution of thorium and uranium doped britholite ceramics. Journal of Nuclear Materials 2010;404:33-43.

[13] Jillavenkatesa A, Condrate RA. The infrared and Raman spectra of $\beta$ and $\alpha$ tricalcium phosphate $\left(\mathrm{Ca}_{3}\left(\mathrm{PO}_{4}\right)_{2}\right)$. Spectroscopy letters 1998;31:1619-34. 